\title{
Alcohol consumption and types of cancer: a review
}

\author{
Mohammad Afshar, ${ }^{a}$ Omid Otroshi, ${ }^{b}$ Elahe Elahian, ${ }^{,}$Shahab Papi, ${ }^{\text {, }}$ Razieh Aalipour, \\ Mohammad Pourebrahimi, ${ }^{\mathrm{f}}$ Ladan Fattah Moghaddam, ${ }^{9}$ Morteza Kameli Morandini, ${ }^{\text {h }}$ \\ and Hamid Salehiniya ${ }^{i, j}$
}

\author{
aDepartment of Operating Room, Faculty of Nursing and Midwifery, Kashan University of Medical Sciences, Kashan, Iran.

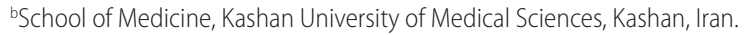 \\ 'Department of Nursing, Borujen Faculty of Nursing, Shahrekord University of Medical Sciences, Shahrekord, Iran. \\ 'Department of Health Education and Promotion, Faculty of health, Tabriz University of Medical Sciences, Tabriz, Iran. \\ eDepartment of Gerontology, University of Social Welfare and Rehabilitation Sciences, Tehran, Iran. \\ fNursing Department, University of Social Welfare and Rehabilitation Sciences, Tehran, Iran. \\ 9Department of Nursing, Faculty of Nursing and Midwifery, Tehran Medical sciences, Islamic Azad University, Tehran, Iran. \\ hDepartment of Nursing, Faculty of Medicine, Sari Branch, Islamic Azad University, Sari, Iran. \\ Social Determinants of Health Research Center, Birjand University of Medical Sciences, Birjand, Iran. \\ 'Department of Epidemiology and Biostatistics, Tehran University of Medical Sciences, Tehran, Iran. \\ Correspondence to Hamid Salehiniya (email: alesaleh70@yahoo.com). \\ (Submitted: 12 April 2019 - Revised version received: 28 April 2019 - Accepted: 10 May 2019 - Published online: 26 October 2019)
}

Objective The purpose of this review study was to investigate the association between alcohol consumption and common cancers.

Methods This study was conducted in English by February 2019 to include studies reporting alcohol consumption related cancer risks through a search in data bases of the PubMed, Scopus and Web of Science. The search strategy included the keywords: "cancer", "alcohol consumption or alcohol drinking or underage drinking". Articles that looked at the relationship between each type of cancer and consumption of alcoholic beverages were entered in to the study and summarized in review.

Results Alcohol consumption is associated with a decreased risk of some types of cancers including: renal cell carcinoma and non-Hodgkin lymphoma. Also, alcohol is independent risk factor for oral and pharyngeal, laryngeal, esophagus, stomach, colorectal, breast and liver cancer. However, further studies are required to confirm the association between alcohol consumption and pancreas, lung, prostate, endometrium, brain tumor and bladder cancer risks.

Conclusion Given the role of excessive alcohol consumption in the occurrence of various types of cancers, there is a need for a comprehensive plan for alcohol abuse in the community.

Keywords cancer, alcohol consumption, underage drinking, alcohol drinking

\section{Introduction}

Alcohol is one of the most preventable causes of injury and mortality in the world and is one of the major risk factors for diseases. ${ }^{1,2}$ Across the world, adult alcohol consumption has been around $38 \%$ over the past 12 months. ${ }^{3}$ According to a study published in 2011, alcohol accounts for $4 \%$ of cancers in the UK. ${ }^{4}$ Most importantly, alcohol is a major risk factor for cancer. Evidence related to the role of alcohol in cancer related to the early $20^{\text {th }}$ century. ${ }^{5}$ Epidemiologic studies and numerous meta-analysis have supported this relationship. ${ }^{5}$ So, the International Agency for Research on Cancer (IARC) in 1988 categorized alcohol as a group one of carcinogens (the highest level in terms of risk). ${ }^{6}$ After the digestion and processing of alcohol in the body, it is changed to a kind of chemical called acetaldehyde, which is the group one carcinogen ${ }^{2,8}$ and prevents DNA repair, subsequently increases the risk of cancer. ${ }^{7}$ Several epidemiological studies have examined the relationship between alcohol drinking and the risk of developing cancer. Based on findings from epidemiological studies, alcohol consumption elevates the risk of various cancers such as breast and intestine $^{8,9}$ and is one of the main risk factors for liver malignancies. ${ }^{10}$ In 2007, the IARC concluded that there is ample evidence that alcohol causes cancer of the mouth, throat, esophagus, larynx, and colorectal. ${ }^{11}$ In some malignancies, such as prostate cancer, this relationship is dose-dependent. ${ }^{12}$ In some other tumors, even taking a small amount of alcohol can increase the risk of cancer; as an illustration, it is associated with colon cancer for every two units of alcohol per day (each unit is $10 \mathrm{ml}$ or $8 \mathrm{~g}$ ) that risk of malignancy is expanded by 9\%. ${ }^{14}$ However, the findings of previous studies suggested that alcohol could reduce the risk of non-Hodgkin's lymphoma (NHL), thyroid cancer and renal cell carcinoma, but the findings of the studies were inconsistent. ${ }^{15-17}$

So far, a large prospective study has examined the relationship between alcohol consumption and cancer risk. However, due to the low number of cases and the existence of contradictory results, in most types of cancers no definitive findings have been reported and the epidemiological evidence that systematically addressed is limited. Therefore, this study aimed to investigate the relationship between alcohol consumption and common cancers of various organs of the body, taking into account possible confounding variables for each organ based on existing evidence and review of the literature.

\section{Materials and Methods}

This study was conducted in English by February 2019 to include epidemiological evidence from all available randomized control trials, case-control and cohort studies reporting alcohol consumption related cancer risks through a search in data bases of the PubMed, Scopus and Web of Science. The search strategy included the keywords: "cancer", 
"alcohol consumption or alcohol drinking or underage drinking". In addition, the reference lists of relevant articles were manually searched to find any other potentially eligible articles. Articles about alcohol consumption amount and types of alcohol beverage are also included in the present study. We excluded reviews, commentaries, articles from overlapping samples, conference abstracts, and articles printed in languages other than English. Articles that looked at the relationship between each type of cancer and alcohol consumption were entered in to the study and summarized in review.

\section{Results}

\section{Study Characteristics}

In the initial electronic literature search, 2236 articles were obtained from data bases and 43 articles were obtained using manual search. After removing duplicates using Endnote X7 $(n=1279)$, the title and abstract of the remaining 1000 articles were reviewed. After this stage, 166 articles were included in the study and 38 of these articles were removed because of scientific reasons and lack of eligible criteria or unrelated to our aim, in all, 128 full papers were reviewed. The most important cancers related to alcohol consumption are summarized in Table 1.

\section{Types of Alcohol-related Cancers Oral and Pharyngeal Cancer}

The findings of a review study between 1988 and 2009 indicated that alcohol consumption is a risk factor for oral and throat cancers, and if combined with tobacco, this effect is multiplied and synergist. On the other hand, the findings revealed that even after controlling for smoking, alcohol consumption was still a risk factor for oral and thymus cancer. ${ }^{18}$ Meta-analysis study findings also showed that the risk of oral

\begin{tabular}{|c|c|c|c|}
\hline Cancer types & Risk factor & Protective & Controversia \\
\hline $\begin{array}{l}\text { Oral and pharyngeal } \\
\text { cancer }\end{array}$ & * & & \\
\hline Laryngeal cancer & * & & \\
\hline Esophagus & * & & \\
\hline Stomach & * & & \\
\hline Colorectal & * & & \\
\hline Liver & * & & \\
\hline Pancreas & & & * \\
\hline Lung & & & * \\
\hline Prostate & & & * \\
\hline Bladder & & & * \\
\hline Breast & * & & \\
\hline Endometrium & & & * \\
\hline Renal cell carcinoma & & * & \\
\hline Brain tumor & & & * \\
\hline $\begin{array}{l}\text { Non-Hodgkin } \\
\text { lymphoma }\end{array}$ & & * & \\
\hline
\end{tabular}

and throat cancer in alcoholics is dose-dependent. ${ }^{19}$ The findings of two meta-analysis studies of more than 30 studies with 14,000 cases showed a significant relationship between alcohol intake and the risk of oral and pharyngeal cancer (OPC), depending on the dose (relative risks, RRs, increasing from 1.29 for $10 \mathrm{~g}$ ethanol/day to 13.02 for $125 \mathrm{~g}$ ethanol/day). ${ }^{19}$ There is a higher RR for cancer of the throat compared with oral cancer, especially in heavy dose. ${ }^{20}$ It is estimated that $30 \%$ of all OPCs worldwide are attributed to alcohol consumption. ${ }^{21}$ Findings from several cohort studies in the United States, Europe and $\mathrm{Asia}^{24-22}$ reported increased risk of oral and throat cancer in alcohol users. Adami et al. ${ }^{25}$ found in a cohort study in Sweden that the risk of oral and throat cancer in alcoholics was four times higher than that of non-alcoholic people (95\% CI: 2.9-5.6). Tønnesen et al. ${ }^{26}$ also reported that the risk of oral and thoracic cancers in alcoholic men was 3.5 times higher than that of non-alcoholic men (95\% CI: 3.0-4.3) and in alcoholic women was 15 times less than non-alcoholic women (95\% CI: 10.8-26.0). In oral and thymus cancer the harmful effects of alcohol in both the intracellular and extracellular levels is observed. In this regard, carcinogens can affect the proliferative activity of the stem cells in basal layer. In patients with oral and thoracic cancer, there is a significant increase in salivary acetaldehyde concentration, which can be related to smoking and poor oral health. Acetaldehyde production can also be increased by alcohol intake through bacterial fluoride. ${ }^{27}$

\section{Laryngeal Cancer}

The association between receiving alcoholic drinks and the spread of laryngeal cancer was first reported in the early 1900s through clinical reports and mortality statistics, and then confirmed by ecological studies. ${ }^{28-30}$ Several studies have confirmed the role of alcohol in laryngeal cancer. ${ }^{31,32}$ The findings of a meta-analysis study in North America, Europe, Japan, and Korea also showed that the risk of laryngeal cancer is significantly elevated if more than one unit of alcohol per day is received. ${ }^{33}$ This risk also increases in non-smokers. ${ }^{34}$ Drinking alcohol through direct contact or solvent action affects laryngeal cancer. ${ }^{35}$ It is estimated that between $50 \%$ and $70 \%$ of all esophageal cancer cases are attributed to alcohol in both sexes. ${ }^{36}$ Ethanol changes the motility and tone of the lower esophagus, the gastric reflux to the esophagus after esophagitis. ${ }^{37}$ This condition increases the risk of Barrett's esophagus or intestinal metaplasia, dysplasia and adenocarcinoma. Chronic inflammation causes more esophagus mucosal damage to nitrosamines and polycyclic aromatic carbohydrates. These ingredients are present in alcoholic drinks. ${ }^{38}$ The relationship between alcohol consumption and the risk of esophageal cancer in various studies (prospective and case-control) has been reported worldwide. ${ }^{39,40}$ In the most recent evaluation by IARC, ethanol in alcoholic drinks has been grouped as one of the carcinogens for humans. ${ }^{41}$ In a second report published by the American Cancer Research Association, alcohol was identified as one of the escalating causes of esophageal cancer. ${ }^{42}$ Therefore, drinking alcohol is known as one of the risk factors for esophageal cancer.

The risk of esophageal malignancy is dosedependent. ${ }^{1,43,44}$ When alcohol is consumed with smoking, the relative risk (RR) of the disease increases significantly. In case of 20 cigarettes per day with one to four units per day, $\mathrm{RR}$ increases by 1.5 times. By taking four to eight units per 
day, RR increases to 12.3; and if you take more than eight units per day, RR will increase 44.4 -fold. ${ }^{45}$ Given that most alcoholics, addicts to tobacco, the synergistic effects of this compound are very important. ${ }^{43}$ The findings of a metaanalysis study showed that alcohol consumption could increase the risk of gastric cancer with odds ratio (OR) of 39/1 (95\% CI: 1.20-1.61), even in the case of low alcohol consumption. ${ }^{46}$ Findings from several recent studies have reported that drinking alcohol can increase the risk of gastric cancer, and its main mechanism is probably related to primary metabolites and stalled individuals, which has a topical toxic effect and soars the risk of gastric cancer.

\section{Stomach}

The findings of a meta-analysis study revealed that alcohol consumption even in the case of low dose could increase the risk of gastric cancer with odds ratio (OR) of 39/1 (95\% CI: $1.20-1.61){ }^{46}$ Findings from several recent studies have reported that drinking alcohol can raise the risk of gastric cancer, and its main mechanism is probably related to primary metabolites and acetaldehydes, which has a topical toxic effect and increases the risk of gastric cancer. ${ }^{47,48}$ The relationship between drinking alcohol and the risk of gastric cancer is biologically plausible; ethanol is one of the soluble fats and may cause damage to the stomach mucosa. Acetaldehyde metabolite may have a topical toxic effect that may be related to gastric cancer. ${ }^{49}$ Ethanol pathogenesis is associated with gastric mucosal injury with impairment in the balance of gastric mucus defense and external invasion. ${ }^{50,51}$

\section{Colorectal}

Several epidemiological studies have shown that increasing alcohol consumption is one of the risk factors for colorectal cancer. The findings of the review and meta-analysis studies $^{8,52-54}$ and several meta-analysis surveys on case and control cohort studies indicate that alcohol intake is associated with an elevation in colorectal cancer. ${ }^{55,56}$ The findings of several meta-analysis studies showed a positive relationship between alcohol consumption and colorectal cancer, and this relationship is dose-dependent. ${ }^{43,57,58}$ Several studies also found that with a chronic consumption of about $50 \mathrm{~g}$ per day of alcohol, the relative risk of colon cancer was $10-20 \% .{ }^{43,59}$ The findings of Dashti et al.$^{60}$ revealed that alcohol consumption, especially more than $28 \mathrm{~g}$ per day of ethanol, is associated with colon cancer.

\section{Liver}

Several studies in various countries have examined the relationship between alcohol consumption and the risk of developing liver cancer (also called HCC) and have confirmed this relationship. ${ }^{61-63}$ Based on systematic and meta-analytic findings, the relative risk of liver cancer for low levels, hazardous and harmful of alcohol consumption, as compared with those who have never consumed alcohol, is respectively $1.45 \%$, $0.33 \%$, and $3.60 \%$ (low consumption $=0-19.90 \mathrm{~g}$ for females and $039.99 \mathrm{~g}$ for males, pure alcohol per day), hazardous consumption $=($ females $20-39.99 \mathrm{~g}$, males $40-59.99 \mathrm{~g})$, harmful consumption $=($ females $40+\mathrm{g}$, males $60+\mathrm{g}) \cdot{ }^{64}$

The main role of gastric cancer following alcohol using is acetaldehyde produced by bacterial flora. ${ }^{43}$ The findings from a meta-analysis study on 19 cohort studies estimated an increase of $16 \%$ in liver cancer among those who consumed at least three units of alcohol daily, compared with non-infected individuals ${ }^{65}$ In fact, in alcoholic people, prolonged and severe alcohol consumption leads to alcoholic cirrhosis, which is a pathogenic stage in liver carcinogenesis. ${ }^{66}$ Along with the carcinogenicity of acetaldehyde, which is the first metabolite of alcohol, other biological mechanisms also explain the effect of alcohol consumption on hepatocarcinogenesis. These include chronic inflammation, the consequences of increased oxidative stress, the induction of cytochrome P-450 2E1, lipid peroxidation and DNA damage, diminished antioxidant defense and DNA repair, reduction of hepatic retinoic acid, excess iron loading, and immune deficiency. ${ }^{67}$

\section{Pancreas}

Findings from a prospective study in the United States revealed that alcohol consumption, in particular consumption liquor, at least three units per day increased pancreatic cancer independent of smoking. ${ }^{68}$ Although the findings of some cohort studies $^{62,69,70}$ and three meta-analysis studies ${ }^{71-73}$ showed that there is a positive and significant relationship between alcohol consumption and the risk of pancreatic cancer, other cohort studies ${ }^{72,74,75}$ did not reveal this relationship. Heavy alcohol consumption causes acute and chronic pancreatitis, but has never been associated with liver cancer. ${ }^{68}$ Findings from a meta-analysis study in 2016 demonstrated that low to moderate alcohol intake did not significantly correlate with the risk of pancreatic cancer, while receiving high amounts of alcohol as well as alcohol drinks increase the risk of pancreatic cancer. ${ }^{76}$ Several biological mechanisms have been proposed to explain the increased risk of pancreatic cancer following heavy alcohol use. Alcohol can cause to inflammatory responses that would lead to overt chronic pancreatitis or diabetes mellitus by inducing mitogenic stimulation. ${ }^{77,78}$ Alcohol consumption also causes asymptomatic chronic pancreatitis, which eventually results in pancreatic cancer, ${ }^{79-81}$ although the prevalence of pancreatitis history in the total population of patients with pancreatic cancer is very low.

\section{Lung}

An elevated risk of lung cancer in the general population has been reported in numerous cohort studies. ${ }^{43}$ The findings of the study, Korte et al. ${ }^{82}$ revealed that for doses greater than five units per day, the relative risk was between 1.53 and 1.88 . There is a positive correlation between alcohol consumption and lung cancer in several reported studies. ${ }^{83-85}$ However, the protective effect of low to moderate alcohol in reducing the incidence of lung cancer has been reported in several studies ${ }^{85-87}$ Rohrmann et al. ${ }^{86}$ found that the anti-inflammatory, antioxidant, and anti-mutagenic effects of intermediate ethanol produce protective effects. Although this protective effect is only specific for lung cancer and is not observed for other neoplasms. ${ }^{88}$

\section{Prostate}

Over the past few decades, a number of overviews and meta-analysis have examined the relationship between prostate cancer and alcohol consumption. ${ }^{89-92}$ According to the findings of Longnecker ${ }^{91}$ and Morton et al., ${ }^{90}$ there was no association between alcohol consumption and prostate cancer. Breslow and Weed ${ }^{93}$ reviewed 32 studies and reported only six studies that found association between alcohol consumption and prostate cancer. 
The findings of Dennis's ${ }^{93}$ meta-analysis on six cohorts and 27 cases-control did not confirm this relationship. Dagnelie et al. ${ }^{89}$ reviewed nine prostate cancer and alcohol studies, and found that in six studies, such a relationship was not confirmed; in two studies, the risk was increased and decreased in one study. The findings of the meta-analysis ${ }^{88}$ showed that the small, but significant risk of prostate cancer in men who consumed more than $50 \mathrm{~g}$ of alcohol per day was observed at a higher risk for men who consumed more than $100 \mathrm{~g}$ per day of alcohol, but there was no significant doseresponse relation. This study first considered potential confounders, between the study variables and the moderating effects of tobacco use. Findings from Middleton Fillmore et al. ${ }^{92}$ revealed that there was a significant relationship between heavy alcohol consumption after controlling the effects of age, study population, design, and study variables. Rota et al. ${ }^{95}$ obtained a significantly higher RR of prostate cancer for each drinking alcohol, low (less than or equal to one drink per day) and moderate (greater than one and less than four drink per day) versus abstaining or occasionally alcohol consumption, but the analysis did not show a meaningful relationship with heavy drinking (greater than or equal to four drinks per day). Overall, the findings of recent meta-analysis and review studies showed a positive relationship, but none of the studies sufficiently controlled the effects of confounding variables, including incorrect categorization of former alcoholics and occasional alcoholics.

\section{Bladder}

The role of alcoholic drinks in bladder carcinogenesis has been studied in several epidemiologic studies. ${ }^{96,97}$ According to Framingham Heart Study, ${ }^{98}$ there was no significant relationship between alcohol consumption and bladder cancer. However, the findings of a meta-analysis study of ureteric cancers showed a slight increase of $1.3 \%$ for current alcoholic-drinkers compared with non-alcoholic ones. ${ }^{99}$ The findings of specific drinks analyze also revealed uncertain results. Some studies have depicted a higher risk for liquor drinks ${ }^{98-101}$ and showed an inverse relationship to beer drink. ${ }^{98,102}$ The average consumption of alcoholic drinks can prevent from coronary artery disease, diabetes mellitus, ${ }^{103,104}$ renal cell carcinoma, ${ }^{105,106}$ prostate cancer, ${ }^{107}$ and $\mathrm{NHL}^{108}$ may be due to mechanisms such as improves immune response and increases insulin sensitivity. One of the possible mechanisms of the protective effect of alcohol consumption in bladder cancer is the urogenous contact hypothesis. ${ }^{109-111}$ Meta-analysis study findings showed that drinking beer and wine reduces the risk of bladder cancer. ${ }^{12}$ Other mechanisms include anti-inflammatory properties of alcohol $^{96,113}$ and anticholinergic effects of polyphenols in red wine ${ }^{114}$ and beer.

Despite the publication of numerous studies in this regard, the role of definitive alcohol on bladder cancer, the effect of various types of alcoholic drinks, patterns of drinking and the role of other factors such as smoking and the frequency of urination for bladder cancer have not yet been proven.

\section{Breast}

About $4-5 \%$ of all breast cancers are associated with alcohol consumption, and $60 \%$ of alcohol-related tumors in women are breast cancer. ${ }^{118}$ Several epidemiological studies have shown a positive relationship between alcohol consumption and breast cancer. ${ }^{119,120}$ This risk occurs even with the average consumption of alcohol. For increasing the amount of ethanol consumed daily by $10 \mathrm{~g}$, RR growth by $10 \% .{ }^{119,121}$

Kwan et al. ${ }^{122}$ found that the risk of recurrence of breast cancer significantly increased in women who had been breast cancer before (especially after menstruation), taking three to four times per week. Systematic study findings showed that alcohol consumption could extend the risk of breast cancer, especially in postmenopausal women. ${ }^{123}$ The pathogenic mechanism of the disease was certainly due to oxidative stress induced by acetaldehyde and nutritional changes (folate, Vitamin B6 and B12), but the main cause of it is interaction with estrogen. It is known that estrogen is metabolized by $\mathrm{ADH}$ and therefore acts in competition with ethanol. Especially high concentrations of acetaldehyde are associated with high levels of estrogen during the menstrual cycle. ${ }^{43}$

\section{Endometrium}

A cohort study found that alcohol consumption of two units or more could increase the risk of endometrial cancer in women after menstruation. However, there was no such relationship in people who consume less than one drink or one to two drinks per day. ${ }^{124}$ The role of unopposed estrogens in endometrial cancer etiology has been confirmed. ${ }^{125}$

Daily use of alcohol is associated with high levels of circulating estrogen in postmenopausal women. ${ }^{126-128}$ Alcohol consumption also raise the estrogen levels in postmenopausal women with estrogen replacement therapy. ${ }^{129,130}$ Therefore, it is likely that women drinking alcoholic drinks are at enhanced risk for endometrial cancer. However, the findings of a prospective study between the 1980s and 2010 on 6807 women who participated in the study found that drinking $<5 \mathrm{~g}$ daily (about half a day) would reduce the risk of endometrial cancer by $22 \%$ (multivariable $\mathrm{RR}=0.78$; $95 \% \mathrm{CI}$ : $0.66-0.94$ ). Getting more alcohol does not; however, produce a protective effect against endometrial cancer [multivariable RRs for 5-14.9 g (one drink), 15-29.9 g (two drinks), or $\geq 30 \mathrm{~g}$ (two drinks)] versus $0 \mathrm{~g}$ per day were $0.88,0.83$, and 0.78 (95\% CI: $0.49-1.25)$, respectively. ${ }^{131}$

\section{Renal Colon Carcinoma}

The implications of a meta-analysis study on 15 case-control studies revealed an inverse relationship between alcohol consumption and renal cell carcinoma (OR 0.67, 95\% CI: 0.62-0.73). The dose-response meta-analysis manifested that an increase in alcohol consumption of $12 \mathrm{~g}$ of ethanol per day was associated with a significant reduction of $5 \%$ risk of renal cell carcinoma. $^{132}$

Other study findings from 12 prospective studies also indicated an inverse relationship between alcohol consumption and renal cell carcinoma. ${ }^{133}$

The findings of another meta-analysis study in 2012 showed an inverse relationship between alcohol consumption and renal cell carcinoma in both genders. It was also observed that drinking one drink per day has protective effects, but drinking too much does not have protective effects. ${ }^{134}$

\section{Brain tumor}

Alcohol is able to cross the cerebrospinal fluid and is therefore a risk factor for brain cancer. ${ }^{135,136}$ Ethanol is oxidized to acetaldehyde which is a genotoxic metabolite in the brain. ${ }^{137}$ Alcohol consumption is in relation to the risk of brain cancer 
in adults has been studied in a number of studies from the early $1970 \mathrm{~s}^{138}$ and usually inconsistent findings revealed in both general use and for various types of alcoholic drinks. For instance, the findings of a cohort study on glioblastoma, which is a type of brain cancer with a low survival rate, showed that there is a dose risk with increasing alcohol consumption for this cancer. ${ }^{139}$ This finding was similar for beer and wine. On the other hand, according to a study of 908 cases of brain cancer, there was no correlation between alcohol consumption and brain cancer, and a relative risk of 1.17 reported for taking more than 15 drinks per week compared with drinking occasionally (for example less than two drinks per week). ${ }^{140}$ Systematic and meta-analytical findings from 19 studies involving 4200 cases of brain cancer suggest that there is no significant relationship between alcohol consumption and adult brain cancer, although further studies are needed to investigate the potential effects of high doses of alcohol. ${ }^{141}$ Findings of another meta-analysis study on 19 observational studies showed that there is no significant relationship between alcohol consumption and the risk of glioma. ${ }^{142}$

\section{Non-Hodgkin's Lymphoma}

According to The Monograph 96 of the IARC, published in $2007,{ }^{135}$ the risk of NHL in alcohol users was lower than those who did not consume alcohol. Similar results were obtained by the next IARC. ${ }^{143}$ In addition, the World Cancer Research Fund (WCRF) reported that there was an inverse relationship between drinking alcohol and NHL. ${ }^{143}$ The results of a meta-analysis study manifested that the risk of NHL among alcohol users is $15 \%$ less than those who do not consumed alcohol. ${ }^{144}$

\section{Conclusion}

The purpose of this review study was to investigate the association between alcohol consumption and the incidence of common cancers. Based on the results of studies, alcohol is associated with a reduction in the risk of renal cell carcinoma and NHL. Conversely, alcohol is a risk factor for oral and thoracic cancers, larynx, esophagus, stomach, colorectal, liver and breast. However, further studies are needed to confirm definitively the association between alcohol and the development of pancreatic, lung, prostate, bladder, endometrial and brain tumors. Given the role of excessive alcohol consumption in the occurrence of various types of cancers, there is a necessity for planning a comprehensive project for alcohol abuse in the community.

\section{Conflicts of Interest}

None.

\section{References}

1. Rehm J, Mathers C, Popova S, Thavorncharoensap M, Teerawattananon Y, Patra J. Global burden of disease and injury and economic cost attributable to alcohol use and alcohol-use disorders. Lancet. 2009;373:2223-2233.

2. Ezzati M, Lopez AD, Rodgers A, Vander Hoorn S, Murray CJ, Comparative Risk Assessment Collaborating Group. Selected major risk factors and global and regional burden of disease. Lancet. 2002:360:1347-1360.

3. World Health Organization, Unit WHOMoSA. Global Status Report on Alcohol and Health 2014. World Health Organization, Geneva, 2014

4. Leitzmann MF, Koebnick C, Freedman ND, Park Y, Ballard-Barbash R, Hollenbeck AR, et al. Physical activity and head and neck cancer risk. Cancer Causes Control. 2008;19:1391-1399.

5. Newsholme A. The possible association of the consumption of alcohol with excessive mortality from cancer. Br Med J. 1903:2:1529-1531.

6. McGuire S. World cancer report 2014. Geneva, Switzerland: World Health Organization, International agency for research on cancer, WHO Press, 2015. Adv Nutr. 2016;7:418-419

7. IARC Working Group on the Evaluation of Carcinogenic Risks to Humans. Personal habits and indoor combustions. Volume100 E. A review of human carcinogens. IARC Monogr Eval Carcinog Risks Hum. 2012;100:1-538.

8. Corrao G, Bagnardi V, Zambon A, La Vecchia C. A meta-analysis of alcohol consumption and the risk of 15 diseases. Prev Med. 2004;38:613-9.

9. Fedirko V, Tramacere I, Bagnardi V, Rota M, Scotti L, Islami F, et al. Alcohol drinking and colorectal cancer risk: an overall and dose-response metaanalysis of published studies. Ann Oncol. 2011;22:1958-1972.

10. Stickel F, Schuppan D, Hahn E, Seitz H. Cocarcinogenic effects of alcohol in hepatocarcinogenesis. Gut. 2002:51:132-9.

11. Jemal A, Bray F, Center MM, Ferlay J, Ward E, Forman D. Global cancer statistics. CA Cancer J Clin. 2011;61:69-90.

12. Zhao J, Stockwell T, Roemer A, Chikritzhs T. Is alcohol consumption a risk factor for prostate cancer? A systematic review and meta-analysis. BMC Cancer. 2016:16:845.

13. Burton R, Henn C, Lavoie D, O'Connor R, Perkins C, Sweeney K, et al. A rapid evidence review of the effectiveness and cost-effectiveness of alcohol control policies: an English perspective. Lancet. 2017;389: $1558-1580$

14. Ferrari P, Jenab M, Norat T, Moskal A, Slimani N, Olsen A, et al. Lifetime and baseline alcohol intake and risk of colon and rectal cancers in the European prospective investigation into cancer and nutrition (EPIC). Int J Cancer 2007;121:2065-2072

15. World Health Organization. Global Strategy on Diet, Physical Activity and Health. World Health Organization, Geneva, 2004.

16. Phongsavan P, Merom D, Marshall A, Bauman A. Estimating physical activity level: the role of domestic activities. J Epidemiol Community Health 2004;58:466-467

17. Levi F, La Vecchia C, Negri E, Franceschi S. Selected physical activities and the risk of endometrial cancer. Br J Cancer. 1993;67:846-851

18. Goldstein BY, Chang SC, Hashibe M, La Vecchia C, Zhang ZF. Alcohol consumption and cancer of the oral cavity and pharynx from 1988 to 2009: an update. Eur J Cancer Prev. 2010;19:431-465.

19. Tramacere I, Negri E, Bagnardi V, Garavello W, Rota M, Scotti L, et al. A metaanalysis of alcohol drinking and oral and pharyngeal cancers. Part 1: overal results and dose-risk relation. Oral Oncol. 2010:46:497-503.

20. Turati F, Garavello W, Tramacere I, Bagnardi V, Rota M, Scotti L, et al. A metaanalysis of alcohol drinking and oral and pharyngeal cancers. Part 2: results by subsites. Oral Oncol. 2010;46:720-726.

21. Turati F, Garavello W, Tramacere I, Pelucchi C, Galeone C, Bagnardi V, et al. A meta-analysis of alcohol drinking and oral and pharyngeal cancers: results from subgroup analyses. Alcohol Alcohol. 2013:48:107-118.

22. Boeing H, EPIC Working Group on Dietary Patterns. Alcohol and risk of cancer of the upper gastrointestinal tract: first analysis of the EPIC data. IARC Sci Publ. 2002:156:151-154.

23. Boffetta P, Garfinkel L. Alcohol drinking and mortality among men enrolled in an American Cancer Society prospective study. Epidemiology. 1990;1:342-348.

24. Murata M, Takayama K, Choi BC, Pak AW. A nested case-control study on alcohol drinking, tobacco smoking, and cancer. Cancer Detect Prev. 1996:20:557-565.

25. Adami HO, McLaughlin JK, Hsing AW, Wolk A, Ekbom A, Holmberg L, et al. Alcoholism and cancer risk: a population-based cohort study. Cancer Causes Control. 1992:3:419-425.

26. Tønnesen H, Møller H, Andersen JR, Jensen E, Juel K. Cancer morbidity in alcohol abusers. Br J Cancer. 1994;69:327-332

27. Seitz HK, Meier P. The role of acetaldehyde in upper digestive tract cancer in alcoholics. Transl Res. 2007:149:293-297.

28. Wynder EL. Some practical aspects of cancer prevention. N Engl J Med. 1952;246:492-502.

29. Tuyns A. Incidence trends of laryngeal cancer in relation to national alcohol and tobacco consumption. In: Magnus K, ed., Trends in Cancer Incidence Causes and Practical Implications. Washington DC, Hemisphere, pp. 199-214.

30. Devesa SS, Blot WJ, Fraumeni JF. Cohort trends in mortality from oral, esophageal, and laryngeal cancers in the United States. Epidemiology. 1990;1:116-121. 
31. IARC Working Group on the Evaluation of Carcinogenic Risks to Humans. Alcohol consumption and ethyl carbamate. IARC Monogr Eval Carcinog Risks Hum. 2010;96:3-1383.

32. Pflaum T, Hausler T, Baumung C, Ackermann S, Kuballa T, Rehm J, et al. Carcinogenic compounds in alcoholic beverages: an update. Arch Toxicol. 2016;90:2349-2367.

33. Islami F, Tramacere I, Rota M, Bagnardi V, Fedirko V, Scotti L, et al. Alcohol drinking and laryngeal cancer: overall and dose-risk relation-A systematic review and meta-analysis. Oral Oncol. 2010:46:802-810.

34. Hashibe M, Brennan P, Benhamou S, Castellsague X, Chen C, Curado MP et al. Alcohol drinking in never users of tobacco, cigarette smoking in never drinkers, and the risk of head and neck cancer: pooled analysis in the International Head and Neck Cancer Epidemiology Consortium. J Natl Cancer Inst. 2007;99:777-789.

35. Altieri A, Garavello W, Bosetti C, Gallus S, La Vecchia C. Alcohol consumption and risk of laryngeal cancer. Oral Oncol. 2005;41:956-965.

36. Popkin BM, Armstrong LE, Bray GM, Caballero B, Frei B, Willett WC. A new proposed guidance system for beverage consumption in the United States. Am J Clin Nutr. 2006;83:529-542

37. Goldenberg D, Golz A, Joachims HZ. The beverage mate: a risk factor for cancer of the head and neck. Head Neck. 2003;25:595-601.

38. Brooks PJ, Enoch MA, Goldman D, Li TK, Yokoyama A. The alcohol flushing response: an unrecognized risk factor for esophageal cancer from alcohol consumption. PLoS Med. 2009;6:e50

39. Bagnardi V, Blangiardo M, La Vecchia C, Corrao G. Alcohol consumption and the risk of cancer: a meta-analysis. Alcohol Res Health. 2001;25:263-270.

40. Oze I, Matsuo K, Wakai K, Nagata C, Mizoue T, Tanaka K, et al. Alcohol drinking and esophageal cancer risk: an evaluation based on a systematic review of epidemiologic evidence among the Japanese population. Jpn J Clin Oncol. 2011;41:677-692.

41. Baan R, Straif K, Grosse Y, Secretan B, El Ghissassi F, Bouvard V, et al. Carcinogenicity of alcoholic beverages. Lancet Oncol. 2007;8:292-293.

42. World Cancer Research Fund and American Institute for Cancer Research Food, Nutrition and the Prevention of Cancer: A Global Perspective. World Cancer Research Fund, Washington, DC, 1997.

43. Testino $\mathrm{G}$. The burden of cancer attributable to alcohol consumption. Maedica (Buchar) 2011;6:313-320

44. Bouvard V, Baan R, Straif K, Grosse Y, Secretan B, El Ghissassi F, et al. A review of human carcinogens_-Part B: biological agents. Lancet Oncol. 2009:10:321-322.

45. Franke A, Teyssen S, Singer MV. Alcohol-related diseases of the esophagus and stomach. Dig Dis. 2005:23:204-213.

46. Ma K, Baloch Z, HeTT, Xia X. Alcohol consumption and gastric cancer risk: a meta-analysis. Med Sci Monit. 2017;23:238-246.

47. Brzozowski T, Konturek PC, Konturek SJ, Kwiecień S, Sliwowski Z, Pajdo R, et al. Implications of reactive oxygen species and cytokines in gastroprotection against stress-induced gastric damage by nitric oxide releasing aspirin. Int J Colorectal Dis. 2003;18:320-329.

48. Kwiecień S, Brzozowski T, Konturek SJ. Effects of reactive oxygen species action on gastric mucosa in various models of mucosal injury. J Physiol Pharmacol. 2002:53:39-50.

49. He H, Chi J. A case-control study of smoking-alcohol consumption and the occurrence of stomach cancer. Chinese J Dis Control. 2012;8:10-20.

50. Wu AH, Wan P, Bernstein L. A multiethnic population-based study of smoking, alcohol and body size and risk of adenocarcinomas of the stomach and esophagus (United States). Cancer Causes Control. 2001;12:721-732.

51. Freedman ND, Abnet CC, Leitzmann MF, Mouw T, Subar AF, Hollenbeck AR, et al. A prospective study of tobacco, alcohol, and the risk of esophagea and gastric cancer subtypes. Am J Epidemiol. 2007;165:1424-1433.

52. Kune GA, Vitetta L. Alcohol consumption and the etiology of colorectal cancer: a review of the scientific evidence from1957 to 1991. Nutr Cancer 1992;18:97-111.

53. Trock B, Lanza E, Greenwald P. Dietary fiber, vegetables, and colon cancer: critical review and meta-analyses of the epidemiologic evidence. J Nat Cancer Inst. 1990;82:650-661.

54. Bagnardi V, Rota M, Botteri E, Tramacere I, Islami F, Fedirko V, et al. Alcohol consumption and site-specific cancer risk: a comprehensive dose-response meta-analysis. Br J Cancer. 2015;112:580-593.

55. Longnecker MP, Orza MJ, Adams ME, Vioque J, Chalmers TC. A meta-analysis of alcoholic beverage consumption in relation to risk of colorectal cancer. Cancer Causes Control. 1990:1:59-68.

56. Berlin JA, Longnecker MP, Greenland S. Meta-analysis of epidemiologic dose-response data. Epidemiology. 1993:4:218-228.
57. Seitz HK, Stickel F. Molecular mechanisms of alcohol-mediated carcinogenesis. Nat Rev Cancer 2007:7:599-612.

58. Wang Y, Duan H, Yang H, Lin J. A pooled analysis of alcohol intake and colorectal cancer. Int J Clin Exp Med. 2015:8:6878-6889.

59. Higginson J, Muir CS, Muñoz N. Human cancer: epidemiology and environmental causes. Cambridge University Press, New York, NY, 1992.

60. Dashti SG, Buchanan DD, Jayasekara H, Ait Ouakrim D, Clendenning M, Rosty $C$, et al. Alcohol consumption and the risk of colorectal cancer for mismatch repair gene mutation carriers. Cancer Epidemiol Biomarkers Prev. 2017;26:366-375

61. Yu MC, MackT, Hanisch R, Peters RL, Henderson BE, Pike MC. Hepatitis, alcohol consumption, cigarette smoking, and hepatocellular carcinoma in Los Angeles. Cancer Res. 1983:43:6077-6079.

62. Austin H, Delzell E, Grufferman S, Levine R, Morrison AS, Stolley PD, et al. A case-control study of hepatocellular carcinoma and the hepatitis B virus, cigarette smoking, and alcohol consumption. Cancer Res. 1986;46:962-966.

63. Wang LY, You SL, Lu SN, Ho HC, Wu MH, Sun CA, et al. Risk of hepatocellular carcinoma and habits of alcohol drinking, betel quid chewing and cigarette smoking: a cohort of $2416 \mathrm{HBsAg}$-seropositive and $9421 \mathrm{HBsAg}$ seronegative male residents in Taiwan. Cancer Causes Control. 2003;14: 241-250.

64. Gutjahr E, Gmel G, Rehm J. Relation between average alcohol consumption and disease: an overview. Eur Addict Res. 2001;7:117-127.

65. Turati F, Galeone C, Rota M, Pelucchi C, Negri E, Bagnardi V, et al. Alcohol and liver cancer: a systematic review and meta-analysis of prospective studies. Ann Oncol. 2014;25:1526-1535.

66. La Vecchia C, Negri E, La Vecchia C, Franceschi S. Liver cirrhosis and the risk of primary liver cancer. Eur J Cancer Prev. 1998;7:315-320.

67. Seitz HK, Stickel F. Risk factors and mechanisms of hepatocarcinogenesis with special emphasis on alcohol and oxidative stress. Biol Chem. 2006:387:349-360.

68. Gapstur SM, Jacobs EJ, Deka A, McCullough ML, Patel AV, Thun MJ. Association of alcohol intake with pancreatic cancer mortality in never smokers. Arch Intern Med. 2011;171:444-451.

69. Hirayama T. Epidemiology of pancreatic cancer in Japan. Japanese J Clin Oncol. 1989:19:208-215.

70. Heinen MM, Verhage BA, Ambergen TA, Goldbohm RA, van den Brandt PA Alcohol consumption and risk of pancreatic cancer in the Netherlands cohort study. Am J Epidemiol. 2009;169:1233-1242.

71. Genkinger JM, Spiegelman D, Anderson KE, Bergkvist L, Bernstein L, van den Brandt PA, et al. Alcohol intake and pancreatic cancer risk: a pooled analysis of fourteen cohort studies. Cancer Epidemiol Biomarkers Prev. 2009;18: 765-776.

72. Michaud DS, Vrieling A, Jiao L, Mendelsohn JB, Steplowski E, Lynch SM, et al. Alcohol intake and pancreatic cancer: a pooled analysis from the pancreatic cancer cohort consortium (PanScan). Cancer Causes Control. 2010;21:12131225.

73. Tramacere I, Scotti L, Jenab M, Bagnardi V, Bellocco R, Rota M, et al. Alcohol drinking and pancreatic cancer risk: a meta-analysis of the dose-risk relation. Int J Cancer. 2010;126:1474-1486.

74. Shibata A, Mack TM, Paganini-Hill A, Ross RK, Henderson BE. A prospective study of pancreatic cancer in the elderly. Int J Cancer. 1994;58:46-49.

75. Gaziano JM, Gaziano TA, Glynn RJ, Sesso HD, Ajani UA, Stampfer MJ, et al. Light-to-moderate alcohol consumption and mortality in the Physicians' Health Study enrollment cohort. J Am Coll Cardiol. 2000;35:96-105

76. Wang YT, Gou YW, Jin WW, Xiao M, Fang HY. Association between alcohol intake and the risk of pancreatic cancer: a dose-response meta-analysis of cohort studies. BMC Cancer. 2016;16:212.

77. Go VL, Gukovskaya A, Pandol SJ. Alcohol and pancreatic cancer. Alcohol. 2005:35:205-211.

78. Welsch T, Kleeff J, Seitz HK, Büchler P, Friess H, Büchler MW. Update on pancreatic cancer and alcohol-associated risk. J Gastroenterol Hepatol. 2006;21:S69-S75

79. Steer ML, Waxman I, Freedman S. Chronic pancreatitis. N Engl J Med. 1995;332:1482-1490.

80. Karlson BM, Ekbom A, Josefsson S, McLaughlin JK, Fraumeni JF, Nyrén O. The risk of pancreatic cancer following pancreatitis: an association due to confounding? Gastroenterology. 1997;113:587-592.

81. Bansal P, Sonnenberg A. Pancreatitis is a risk factor for pancreatic cancer. Gastroenterology. 1995;109:247-251.

82. Korte JE, Brennan P, Henley SJ, Boffetta P. Dose-specific meta-analysis and sensitivity analysis of the relation between alcohol consumption and lung cancer risk. Am J Epidemiol. 2002;155:496-506. 
83. Bagnardi V, Randi G, Lubin J, Consonni D, Lam TK, Subar AF, et al. Alcohol consumption and lung cancer risk in the Environment and Genetics in Lung Cancer Etiology (EAGLE) study. Am J Epidemiol. 2010;171:36-44.

84. Dosemeci M, Gokmen I, Unsal M, Hayes RB, Blair A. Tobacco, alcohol use, and risks of laryngeal and lung cancer by subsite and histologic type in Turkey. Cancer Causes Control. 1997:8:729-737.

85. Prescott E, Grønbæk M, Becker U, Sørensen TI. Alcohol intake and the risk of lung cancer: influence of type of alcoholic beverage. Am J Epidemiol. 1999:149:463-470.

86. Rohrmann S, Linseisen J, Boshuizen HC, Whittaker J, Agudo A, Vineis P, et al. Ethanol intake and risk of lung cancer in the European Prospective Investigation into Cancer and Nutrition (EPIC). Am J Epidemiol. 2006:164:1103-1114.

87. Chao C, Slezak JM, Caan BJ, Quinn VP. Alcoholic beverage intake and risk of lung cancer: the California Men's Health Study. Cancer Epidemiol Biomarkers Prev. 2008;17:2692-2699.

88. Bagnardi V, Blangiardo M, La Vecchia C, Corrao G. A meta-analysis of alcoho drinking and cancer risk. Br J Cancer. 2001:85:1700-1705.

89. Dagnelie P, Schuurman A, Goldbohm R, Van den Brandt P. Diet, anthropometric measures and prostate cancer risk: a review of prospective cohort and intervention studies. BJU Int. 2004;93:1139-1150.

90. Morton MS, Griffiths K, Blacklock N. The preventive role of diet in prostatic disease. Br J Urol. 1996;77:481-493.

91. Longnecker MP. Alcohol consumption and risk of cancer in humans: an overview. Alcohol. 1995;12:87-96.

92. Middleton Fillmore K, Chikritzhs T, Stockwell T, Bostrom A, Pascal R. Alcohol use and prostate cancer: a meta-analysis. Mol Nutr Food Res. 2009;53: 240-255.

93. Breslow RA, Weed DL. Review of epidemiologic studies of alcohol and prostate cancer: 1971-1996. Nutr Cancer. 1998;30:1-13.

94. Dennis LK. Meta-analysis for combining relative risks of alcohol consumption and prostate cancer. Prostate. 2000;42:56-66.

95. Rota M, Scotti L, Turati F, Tramacere I, Islami F, Bellocco R, et al. Alcohol consumption and prostate cancer risk: a meta-analysis of the dose-risk relation. Eur J Cancer Prev. 2012;21:350-359.

96. Jiang X, Castelao JE, Groshen S, Cortessis VK, Ross RK, Conti DV, et al. Alcoho consumption and risk of bladder cancer in Los Angeles County. Int J Cancer. 2007:121:839-845.

97. IARC Alcohol drinking. Biological data relevant to the evaluation of carcinogenic risk to humans. IARC Monogr Eval Carcinog Risks Hum. 1988:44:101-152.

98. Djoussé L, Schatzkin A, Chibnik LB, D’Agostino RB, Kreger BE, Ellison RC. Alcohol consumption and the risk of bladder cancer in the Framingham Heart Study. J Natl Cancer Inst. 2004;96:1397-1400.

99. Zeegers MP, Tan FE, Verhagen AP, Weijenberg MP, van den Brandt PA. Elevated risk of cancer of the urinary tract for alcohol drinkers: a metaanalysis. Cancer Causes Control. 1999:10:445-451.

100. Zeegers MP, Volovics A, Dorant E, Goldbohm RA, van den Brandt PA. Alcohol consumption and bladder cancer risk: results from The Netherlands Cohort Study. Am J Epidemiol. 2001;153:38-41.

101. Chyou PH, Nomura AM, Stemmermann GN. A prospective study of diet, smoking, and lower urinary tract cancer. Ann Epidemiol. 1993;3:211-216.

102. Pelucchi C, Negri E, Franceschi S, Talamini R, La Vecchia C. Alcohol drinking and bladder cancer. J Clin Epidemiol. 2002;55:637-641.

103. Gunzerath L, Faden V, Zakhari S, Warren K. National Institute on Alcohol Abuse and Alcoholism report on moderate drinking. Alcohol Clin Exp Res. 2004;28:829-847

104. Beulens JW, Stolk RP, van der Schouw YT, Grobbee DE, Hendriks HF, Bots $\mathrm{ML}$. Alcohol consumption and risk of type2 diabetes among older women. Diabetes Care 2005;28:2933-2938.

105. Asal NR, Risser DR, Kadamani S, Geyer JR, Lee ET, Cherng N. Risk factors in renal cell carcinoma: I. Methodology, demographics, tobacco, beverage use, and obesity. Cancer Detect Prev. 1988:11:359-377.

106. Parker AS, Cerhan JR, Lynch CF, Ershow AG, Cantor KP. Gender, alcohol consumption, and renal cell carcinoma. Am J Epidemiol. 2002;155: 455-462.

107. Baglietto L, Severi G, English DR, Hopper JL, Giles GG. Alcohol consumption and prostate cancer risk: results from the Melbourne collaborative cohort study. Int J Cancer 2006;119:1501-1504.

108. Morton LM, Zheng T, Holford TR, Holly EA, Chiu BC, Costantini AS, et al. Alcohol consumption and risk of non-Hodgkin lymphoma: a pooled analysis. Lancet Oncol. 2005:6:469-476.

109. Negri E, La Vecchia C. Epidemiology and prevention of bladder cancer. In: Bassi P, Pagano F, eds. Invasive Bladder Cancer. Springer, London, 2007. pp. 1-14.
110. Cohen SM, Johansson SL. Epidemiology and etiology of bladder cancer. Urol Clin North Am. 1992;19:421-428.

111. Michaud DS, Spiegelman D, Clinton SK, Rimm EB, Curhan GC, Willett WC, et al. Fluid intake and the risk of bladder cancer in men. N Engl J Med. 1999;340:1390-1397.

112. Mao Q, Lin Y, Zheng X, Qin J, Yang K, Xie L. A meta-analysis of alcohol intake and risk of bladder cancer. Cancer Causes Control. 2010;21: 1843-1850.

113. Sierksma A, van der Gaag M, Kluft C, Hendriks H. Moderate alcohol consumption reduces plasma C-reactive protein and fibrinogen levels; a randomized, diet-controlled intervention study. Eur J Clin Nutr. 2002;56:1130-1136.

114. Luceri C, Caderni G, Sanna A, Dolara P. Red wine and black tea polyphenols modulate the expression of cycloxygenase-2, inducible nitric oxide synthase and glutathione-related enzymes in azoxymethane-induced f344 rat colon tumors. J Nutr. 2002;132:1376-1379.

115. Stevens JF, Page JE. Xanthohumol and related prenylflavonoids from hops and beer: to your good health! Phytochemistry. 2004;65:1317-1330.

116. Gerhauser C, Alt A, Heiss E, Gamal-Eldeen A, Klimo K, Knauft J, et al. Cancer chemopreventive activity of Xanthohumol, a natural product derived from hop. Mol Cancer Ther. 2002;1:959-969.8

117. Zhao F, Nozawa H, Daikonnya A, Kondo K, Kitanaka S. Inhibitors of nitric oxide production from hops (Humulus lupulus L.). Biol Pharm Bull. 2003;26:61-65.

118. Chen WY, Rosner B, Hankinson SE, Colditz GA, Willett WC. Moderate alcohol consumption during adult life, drinking patterns, and breast cancer risk. JAMA. 2011:306:1884-1890.

119. Cancer CGoHFiB. Alcohol, tobacco and breast cancer - collaborative reanalysis of individual data from 53 epidemiological studies, including 58,515 women with breast cancer and 95,067 women without the disease. Br J Cancer. 2002; 87:1234-1245.

120. Smith-Warner SA, Spiegelman D, Yaun SS, van den Brandt PA, Folsom AR, Goldbohm RA, et al. Alcohol and breast cancer in women: a pooled analysis of cohort studies. JAMA 1998;279:535-540.

121. Willett WC, Stampfer MJ, Colditz GA, Rosner BA, Hennekens CH, Speizer FE. Moderate alcohol consumption and the risk of breast cancer. $\mathrm{N}$ Engl J Med. 1987;316:1174-1180

122. Kwan ML, Kushi LH, Weltzien E, Tam EK, Castillo A, Sweeney C, et al. Alcohol consumption and breast cancer recurrence and survival among women with early-stage breast cancer: the life after cancer epidemiology study. J Clin Oncol. 2010;28:4410-4416.

123. Simapivapan $P$, Boltong A, Hodge A. To what extent is alcohol consumption associated with breast cancer recurrence and second primary breast cancer?: a systematic review. Cancer Treat Rev. 2016:50:155-167.

124. Setiawan VW, Monroe KR, Goodman MT, Kolonel LN, Pike MC, Henderson BE. Alcohol consumption and endometrial cancer risk: the multiethnic cohort. Int J Cancer. 2008;122:634-638.

125. Akhmedkhanov A, Zeleniuch-Jacquotte A, Toniolo P. Role of exogenous and endogenous hormones in endometrial cancer: review of the evidence and research perspectives. Ann N Y Acad Sci. 2001;943:296-315.

126. Gavaler JS, Van Thiel DH. The association between moderate alcoholic beverage consumption and serum estradiol and testosterone levels in normal postmenopausal women: relationship to the literature. Alcohol Clin Exp Res. 1992;16:87-92. DOI: 10.1111/j.1530-0277.1992.tb00642.x

127. Hankinson SE, Willett WC, Manson JE, Hunter DJ, Colditz GA, Stampfer MJ, et al. Alcohol, height, and adiposity in relation to estrogen and prolactin levels in postmenopausal women. J Natl Cancer Inst. 1995:87: 1297-1302.

128. Onland-Moret NC, Peeters PH, van der Schouw YT, Grobbee DE, van Gils CH. Alcohol and endogenous sex steroid levels in postmenopausal women: a cross-sectional study. J Clin Endocrinol Metab. 2005;90: 1414-1419.

129. Purohit V. Moderate alcohol consumption and estrogen levels in postmenopausal women: a review. Alcohol Clin Exp Res. 1998:22:994-997.

130. Ginsburg ES. Estrogen, alcohol and breast cancer risk. J Steroid Biochem Mol Biol. 1999:69:299-306.

131. Je Y, De Vivo I, Giovannucci E. Long-term alcohol intake and risk of endometrial cancer in the Nurses' Health Study, 1980-2010. Br J Cancer. 2014;111:186-194

132. Cheng G, Xie L. Alcohol intake and risk of renal cell carcinoma: a metaanalysis of published case-control studies. Arch Med Sci. 2011;7:648-657.

133. Lee JE, Hunter DJ, Spiegelman D, Adami HO, Albanes D, Bernstein L, et al. Alcohol intake and renal cell cancer in a pooled analysis of 12 prospective studies. J Natl Cancer Inst. 2007;99:801-810 
134. Song DY, Song S, Song Y, Lee JE. Alcohol intake and renal cell cancer risk: a meta-analysis. Br J Cancer 2012;106:1881-1890.

135. International Agency for Research on Cancer. Alcohol Consumption and Ethyl Carbamate, Vol. 96. International Agency for Research on Cancer, Lyon, France, 2010.

136. Wrensch M, Bondy ML, Wiencke J, Yost M. Environmental risk factors for primary malignant brain tumors: a review. J Neurooncol. 1993;17:47-64.

137. Deitrich R, Zimatkin S, Pronko S. Oxidation of ethanol in the brain and its consequences. Alcohol Res Health. 2006;29:266-273.

138. Choi NW, Schuman LM, Gullen WH. Epidemiology of primary centra nervous system neoplasms. II. Case-control study. Am J Epidemiol. 1970;91:467-485.

139. Baglietto L, Giles GG, English DR, Karahalios A, Hopper JL, Severi G. Alcoho consumption and risk of glioblastoma; evidence from the Melbourne Collaborative Cohort Study. Int J Cancer 2011;128:1929-1934.
140. Allen NE, Beral V, Casabonne D, Kan SW, Reeves GK, Brown A, et al. Moderate alcohol intake and cancer incidence in women. J Natl Cancer Inst. 2009;101:296-305

141. Galeone C, Malerba S, Rota M, Bagnardi V, Negri E, Scotti L, et al. A metaanalysis of alcohol consumption and the risk of brain tumours. Ann Oncol. 2013;24:514-523.

142. Qi ZY, Shao C, Yang C, Wang Z, Hui GZ. Alcohol consumption and risk of glioma: a meta-analysis of 19 observational studies. Nutrients 2014;6: 504-516.

143. Secretan B, Straif K, Baan R, Grosse Y, El Ghissassi F, Bouvard V, et al. A review of human carcinogens_-Part E: tobacco, areca nut, alcohol, coal smoke, and salted fish. Lancet Oncol. 2009;10:1033-1034.

144. Tramacere I, Pelucchi C, Bonifazi M, Bagnardi V, Rota M, Bellocco R, et al. Alcohol drinking and non-Hodgkin lymphoma risk: a systematic review and a meta-analysis. Ann Oncol. 2012;23:2791-2798. 